\title{
The $A_{2 B}$ adenosine receptor protects against inflammation and excessive vascular adhesion
}

\author{
Dan Yang, ${ }^{1}$ Ying Zhang, ${ }^{1}$ Hao G. Nguyen, ${ }^{1}$ Milka Koupenova, ${ }^{1}$ Anil K. Chauhan, ${ }^{2}$ Maria Makitalo, ${ }^{1}$ \\ Matthew R. Jones, ${ }^{1}$ Cynthia St. Hilaire, ${ }^{1}$ David C. Seldin, ${ }^{3}$ Paul Toselli, ${ }^{1}$ Edward Lamperti, ${ }^{1}$ \\ Barbara M. Schreiber, ${ }^{1}$ Haralambos Gavras,, ${ }^{3}$ Denisa D. Wagner,2 and Katya Ravid1,3 \\ ${ }^{1}$ Department of Biochemistry and Whitaker Cardiovascular Institute, Boston University School of Medicine, Boston, Massachusetts, USA.
${ }^{2}$ CBR Institute for Biomedical Research and Department of Pathology, Harvard Medical School, Boston, Massachusetts, USA. \\ ${ }^{3}$ Department of Medicine, Boston University School of Medicine, Boston, Massachusetts, USA.
}

\begin{abstract}
Adenosine has been described as playing a role in the control of inflammation, but it has not been certain which of its receptors mediate this effect. Here, we generated an $A_{2 B}$ adenosine receptor-knockout/reporter

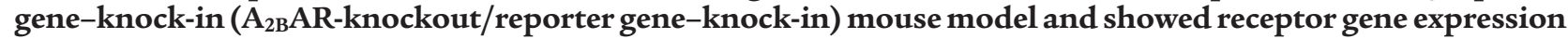
in the vasculature and macrophages, the ablation of which causes low-grade inflammation compared with age-, sex-, and strain-matched control mice. Augmentation of proinflammatory cytokines, such as TNF- $\alpha$, and a consequent downregulation of $I \kappa B-\alpha$ are the underlying mechanisms for an observed upregulation of adhesion molecules in the vasculature of these $A_{2 B} A R$-null mice. Intriguingly, leukocyte adhesion to the vascu-

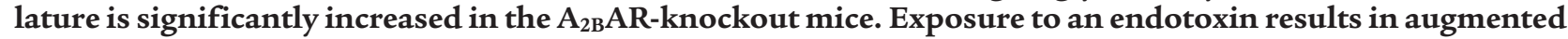
proinflammatory cytokine levels in $\mathrm{A}_{2 \mathrm{~B}} \mathrm{AR}$-null mice compared with control mice. Bone marrow transplantations indicated that bone marrow (and to a lesser extent vascular) $A_{2 \mathrm{~B}} A R s$ regulate these processes. Hence, we identify the $A_{2 \mathrm{~B}} \mathrm{AR}$ as a new critical regulator of inflammation and vascular adhesion primarily via signals from hematopoietic cells to the vasculature, focusing attention on the receptor as a therapeutic target.
\end{abstract}

\section{Introduction}

Based on pharmacologic studies, the $G$ protein-coupled adenosine receptors were initially classified into adenylyl cyclase inhibitory $\left(A_{1}\right.$ and $\left.A_{3}\right)$ and stimulatory $\left(A_{2}\right)$ categories $(1,2)$. Further classification of $\mathrm{A}_{2}$ adenosine receptors $\left(\mathrm{A}_{2} \mathrm{ARs}\right)$ into subtypes $2_{\mathrm{A}}$ and $2_{\mathrm{B}}$ $(3,4)$ was determined by the presence of high-affinity $A_{2 A} A R$ and low-affinity $\mathrm{A}_{2 \mathrm{~B}} \mathrm{AR}$ binding sites (5). Subsequent molecular studies identified all 4 genes encoding these receptors (reviewed in ref. 6), and their classification has been endorsed by the International Union of Pharmacology Committee on Receptor Nomenclature and Drug Classification (7). The role of adenosine receptors in cellular or tissue function has been deduced from studies with adenosine ligands (reviewed in ref. 8). Mouse models engineered to harbor a deletion of a specific adenosine receptor have proven to be important in elucidating the function of different adenosine receptors (reviewed in ref. 6). Generation of mice deficient in $\mathrm{A}_{1} \mathrm{ARs}$ has supported previous pharmacological research related to the role of the $A_{1} A R$ in central nervous system and kidney physiology (9). These studies demonstrate that the $A_{1} A R$ is necessary for the tubuloglomerular response to increased flow rate and subsequently impacts renal water and sodium retention. Furthermore, plasma renin activity is increased in $\mathrm{A}_{1}$-deficient mice compared with their WT littermates, suggesting that adenosine regulates renin release via $A_{1} A R s$. Mice lacking functional $A_{1} A R s$ show signs of increased anxiety and hyperalgesia (10). Hypoxia-associated decrease in neuronal activity is less pronounced in $\mathrm{A}_{1} \mathrm{AR}$-null mice, as is recov-

Nonstandard abbreviations used: $\mathrm{A}_{2 \mathrm{~B}} \mathrm{AR}, \mathrm{A}_{2 \mathrm{~B}}$ adenosine receptor; $\mathrm{M}-\mathrm{MLV}$, Moloney murine leukemia virus; NECA, $5^{\prime}-\mathrm{N}$-ethylcarboxamidoadenosine.

Conflict of interest: The authors have declared that no conflict of interest exists.

Citation for this article: J. Clin. Invest. 116:1913-1923 (2006). doi:10.1172/JCI27933. ery of neuronal activity after hypoxia (9). Mice carrying a genetic deletion of the $\mathrm{A}_{3} \mathrm{AR}$ have been described in several reports. The ability of an $\mathrm{A}_{3 \mathrm{~A}} \mathrm{AR}$ selective ligand to potentiate antigen-dependent degranulation of mast cells, as measured by hexosaminidase release, is lost in mice lacking A3 receptors compared with normal mice (11). Cutaneous vasopermeability is associated with activation and subsequent degranulation of mast cells, and induction of cutaneous vasopermeability by adenosine or inosine, as measured by extravasation of plasma protein, is lost in mice lacking a functional $\mathrm{A}_{3} \mathrm{AR}$ (12). Attenuation of LPS-induced TNF- $\alpha$ production is decreased in these $\mathrm{A}_{3} \mathrm{AR}$-null mice as compared with control mice (11). Studies of BP response to intravenous adenosine injection show a significantly larger drop in BP in mice lacking the $\mathrm{A}_{3} \mathrm{AR}$ compared with control mice (13). Interestingly, ischemiareperfusion injury of mice lacking $\mathrm{A}_{3} \mathrm{ARs}$ results in a significant reduction in infarct size compared with WT mice. No difference in infarct size is seen after preconditioning (14). As to the $\mathrm{A}_{2 \mathrm{~A}} \mathrm{ARs}$, they were the first adenosine receptors to be genetically deleted in a murine model, and over the years several studies have continued to elucidate the role of these receptors in various physiological processes. These animals demonstrate several central nervous system disturbances, including increased BP, decreased exploratory activity, increased aggressiveness and hypoalgesia (15), compensatory alteration in spinal cord opioid receptors (16), attenuated psychostimulant responses $(17,18)$, reduced alcohol sensitivity (19), and reduced alcohol withdrawal-induced seizure (20). Exploratory activity in mice is generally increased by caffeine administration; however, the opposite effect was observed in $\mathrm{A}_{2 \mathrm{~A}}$-null mice, which suggested that caffeine-dependent psychostimulation is mediated by the $A_{2 A} A R(20)$. Activation of $A_{2 A}$ is required for dopaminergic function, since dopamine-mediated cellular response such as 
A
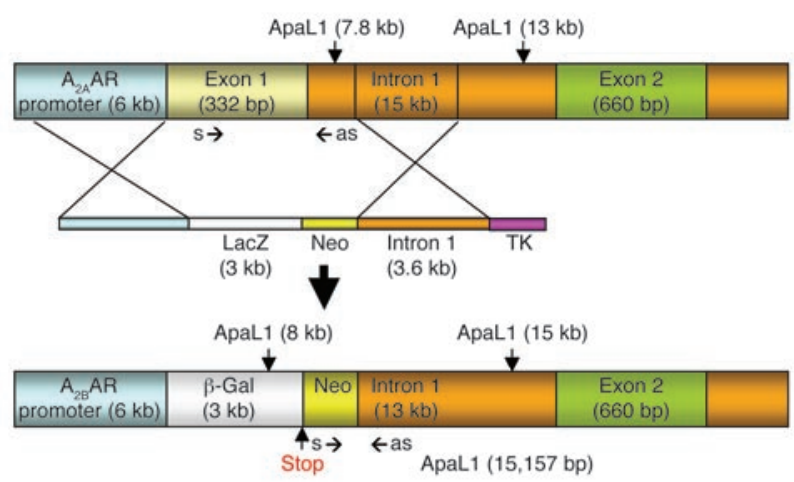

B

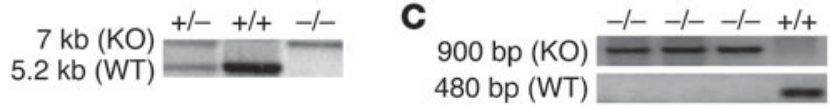

D
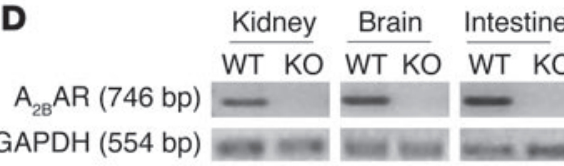

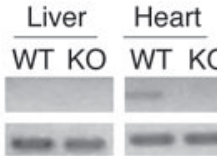

Aorta Lung WT KO WT KO WT ---E

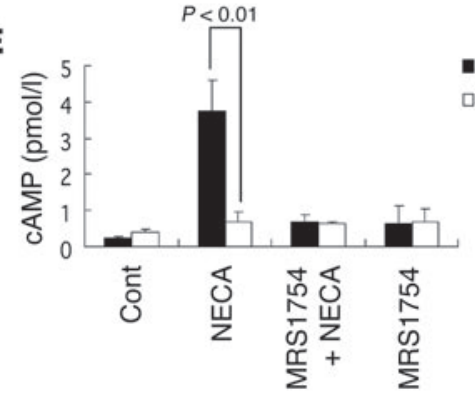

- WT
$\square A_{2 B}$ AR KO

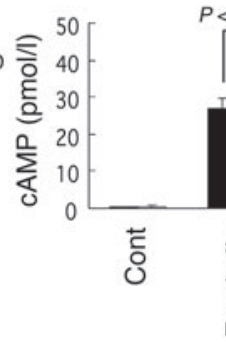

Figure 1

Generation of $A_{2 B} A R-K O$ mice. (A) Scheme of the $A_{2 B} A R$ gene (top), the targeting vector (middle), and the resulting $A_{2 B} A R-K O / \beta$-gal-knock-in gene (bottom). On the latter, the restrictions sites (ApaL1) used to digest genomic DNA for Southern blot analysis of tail genomic DNA (B) are indicated, as well as the sites for sense (s) and antisense (as) primers used for PCR analysis of tail genomic DNA (C). The expected products for the WT (+/+) and KO (-/-) mice are indicated. (D) $A_{2 B} A R$ mRNA in different tissues. RNA was prepared from different tissues derived from WT or KO mice and subjected to RT-PCR to amplify exon 1 as described in Methods. (E) $A_{2 B} A R$ activation in primary aortic VSMCs. CAMP was measured in cells derived from WT or KO mice after treatment with vehicle, $5 \mu \mathrm{M}$ $\mathrm{NECA}$, or $5 \mu \mathrm{M}$ forskolin in the presence or absence of $5 \mu \mathrm{M}$ of the $\mathrm{A}_{2 \mathrm{~B}} \mathrm{AR}$ antagonist MRS1754 as indicated. Data are presented as average \pm SD for 3 experiments performed in duplicate.
DARPP-32 phosphorylation and immediately early gene expression in the striatum were abolished in the $\mathrm{A}_{2 \mathrm{~A}}$-deficient mice (21, 22). Inflammatory stimuli induced higher levels of proinflammatory cytokines and increased tissue damage after injury in mice lacking the $\mathrm{A}_{2 \mathrm{~A}} \mathrm{AR}$ compared with WT mice $(23,24)$. Studies of all the above-described adenosine receptor-null mouse models indicate that extracellular adenosine acting at adenosine receptors results in complex action in various tissues.

Little is known about the cell-specific expression of the $A_{2 B} A R$ in vivo or about the functional significance of the $A_{2 B} A R$, the latter because there is a lack of specific agonists for this receptor. Despite this limitation, the $\mathrm{A}_{2 \mathrm{~B}} \mathrm{AR}$ has been implicated in several important biological events, including mediating vasodilation $(25,26)$, inhibiting growth of rat aortic smooth muscle cells $(27,28)$, and increasing the production of cytokines, such as IL- 6 , by vascular cells $(29,30)$. In vitro studies described the $\mathrm{A}_{2 \mathrm{~B}} \mathrm{AR}$ as mediating augmentation of cytokine production by vascular cells $(29,30)$, and adenosine has been described as a regulator of inflammatory response (31). This was attributed to adenosine receptor-mediated control of cytokine production by macrophages $(32,33)$ and confirmed during analysis of $\mathrm{A}_{2 \mathrm{~A}} \mathrm{AR}$-null mice $(24,34)$. Based on these in vivo studies, among adenosine receptors, the $\mathrm{A}_{2 \mathrm{~A}} \mathrm{AR}$ has been regarded as a main protector against inflammation. However, the direct influence of $\mathrm{A}_{2 \mathrm{~B}} \mathrm{AR}$ on cytokine levels, inflammation, and/or vascular adhesion has not yet been examined in vivo, nor has the relative contribution of bone marrow-derived adenosine receptors or other $\mathrm{A}_{2 \mathrm{~B}} \mathrm{ARs}$ to these processes.
The current study describes the generation of a mouse model with targeted deletion of the $A_{2 B} A R$ gene. Exon 1 of the $A_{2 B} A R$ was replaced by a reporter gene, which allowed examination of endogenous $\mathrm{A}_{2 \mathrm{~B}} \mathrm{AR}$-dependent expression in various tissues and cell types in vivo. Results show that there is abundant reporter expression in the vasculature and in macrophages. This new animal model emphasizes a role for the $\mathrm{A}_{2 \mathrm{~B}} \mathrm{AR}$ in attenuating inflammation, at baseline or in response to endotoxin treatment, by regulating proinflammatory cytokine production and adhesion properties of the vasculature. These effects are primarily mediated via signals from hematopoietic cells to the vasculature, as deduced from bone marrow transplantation experiments. Contrary to the speculated function of $\mathrm{A}_{2 \mathrm{~B}} \mathrm{AR}$ in vasodilation, the $\mathrm{A}_{2 \mathrm{~B}} \mathrm{AR}$-null mice have normal $\mathrm{BP}$ at baseline or in response to adenosine infusion.

\section{Results}

Generation of $A_{2 B} A R$-deficient mice. A targeting construct was generated to inactivate the $A_{2 B} A R$ gene by replacing exon 1 of the $\mathrm{A}_{2 \mathrm{~B}} \mathrm{AR}$ with a reporter construct containing the $\beta$-gal gene (Figure $1 \mathrm{~A}$ ). Successful genomic integration of the mutant allele was determined by Southern blot analysis and PCR as shown in Figure 1, B and C. Furthermore, to confirm $A_{2 B} A R$ gene ablation, $\mathrm{A}_{2 \mathrm{~B}} \mathrm{AR}$ transcripts were quantified in various tissues using RT-PCR (Figure 1D and Supplemental Figure 1A; supplemental material available online with this article; doi:10.1172/JCI27933DS1). Because an antibody specific to mouse $\mathrm{A}_{2 \mathrm{~B}} \mathrm{AR}$ is currently unavailable, the presence or absence of receptor activity was used as an indicator 
A

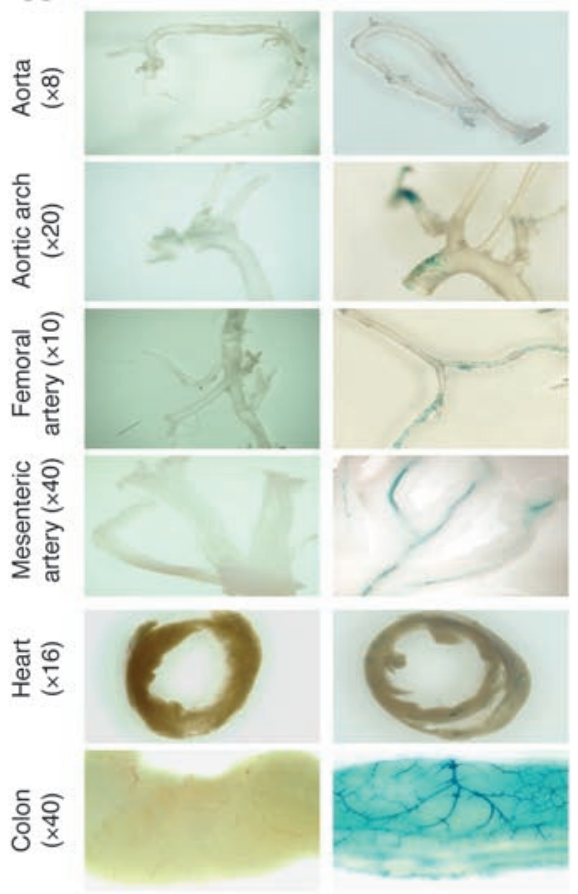

C
B
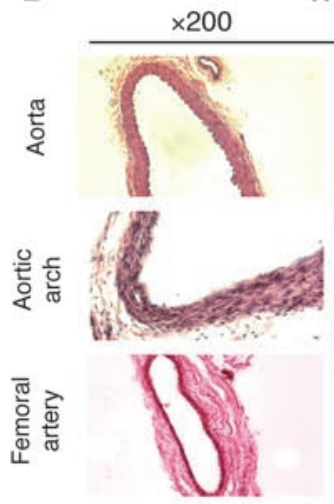

品

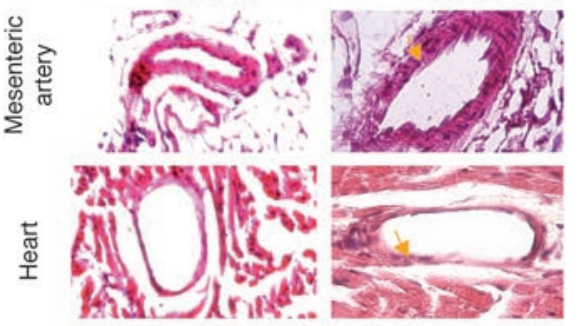
$\times 600$
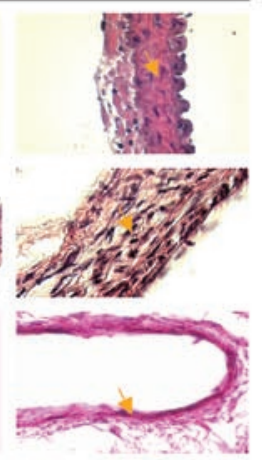

D

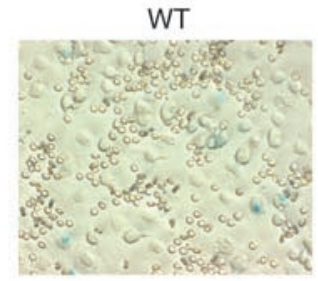

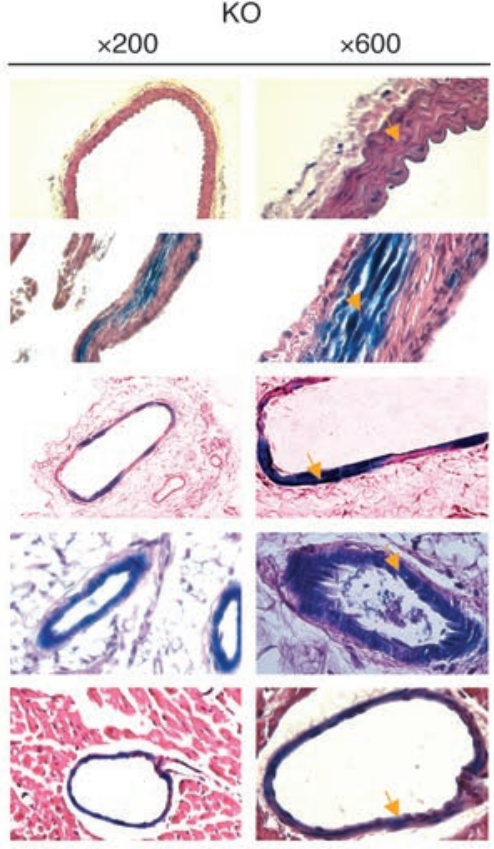

KO

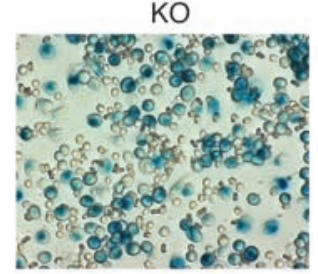

$\mathrm{KO}$ vas deferens artery
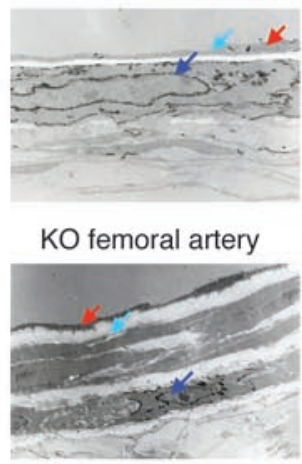
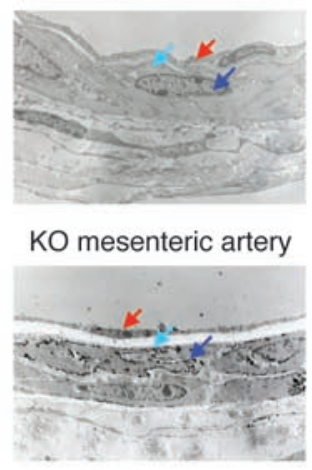

\section{Figure 2}

$\beta$-Gal expression in different tissues. (A) $\beta$-Gal staining of different organs derived from WT or KO mice and captured at the indicated magnifications (in parenthesis on the left) with an Olympus IX70 microscope combined with a Hamamatsu charge-coupled device camera (C4742-95). (B) Histological examination of tissue sections derived from the organs shown in $\mathbf{A}$. The arrows point to the VSMC layer. Fold magnifications of captured images are indicated above each column (×200 or $\times 600)$. (C) Electron microscopic examination of arteries. In order to ascertain $\beta$-gal expression in the endothelial layer and further confirm expression in smooth muscle cells, we applied electron microscopic examination. The red arrow indicates endothelial cells, the light blue arrow elastin, and the dark blue arrow the VSMC layer. Original magnification, $\times 6,400$. The black stain is indicative of $\beta$-gal staining. As control, WT mice were subjected to similar staining, showing no expression. (D) $\beta$-Gal expression was evident in peritoneal macrophages isolated and processed as described in Methods. The isolation procedure yielded a preparation enriched with macrophages (to $35-40 \%$ of total cells).

of protein expression. Figure $1 \mathrm{E}$ shows that the $\mathrm{A}_{2 \mathrm{~A}} \mathrm{AR}$ and $\mathrm{A}_{2 \mathrm{~B}} \mathrm{AR}$ agonist 5 - $N$-ethylcarboxamidoadenosine (NECA) only mildly increased cAMP levels in primary VSMCS derived from KO mice compared with the significant increase in CAMP production in WT VSMCs. Both $\mathrm{A}_{2 \mathrm{~A}} \mathrm{AR}$ and $\mathrm{A}_{2 \mathrm{~B}} \mathrm{AR}$ were previously shown to be expressed in WT primary VSMCs (35). The $\mathrm{A}_{2 \mathrm{~B}} \mathrm{AR}$ selective antagonist MRS1754 eliminated the stimulatory effect of NECA only in WT cells, indicating that $\mathrm{A}_{2 \mathrm{~B}} \mathrm{AR}$ activity is high in these cells and absent in the KO cells. Administration of forskolin (a direct activator of adenylyl cyclase) demonstrated that adenylyl cyclase activity augmented cAMP levels in both WT and $\mathrm{A}_{2 \mathrm{~B}} \mathrm{AR}-$ deficient cells. Similar results were obtained using macrophages (Supplemental Figure 1B).

$\mathrm{A}_{2 \mathrm{~B}} \mathrm{AR}-\mathrm{KO}$ mice bred normally and exhibited normal platelet, red blood, and white cell counts (Supplemental Table 1). For all subsequent studies, age- and sex-matched WT and $\mathrm{A}_{2 \mathrm{~B}} \mathrm{AR}-\mathrm{KO}$ mice were used as detailed in Methods.

$A_{2 B} A R$ expression in different tissues. By replacing exon 1 of the $A_{2 B} A R$ gene with a reporter construct containing $\beta$-gal, tissue-specific activation of the $A_{2 B} A R$ gene promoter was conve- 
A

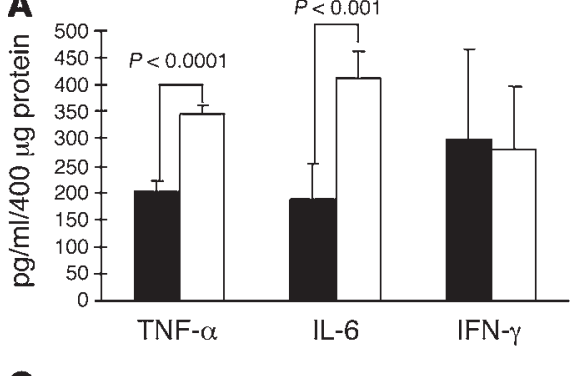

00 $P<0.0001$

C

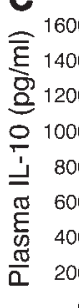

- WT

$\square A_{28} A R K O$

- WT
B
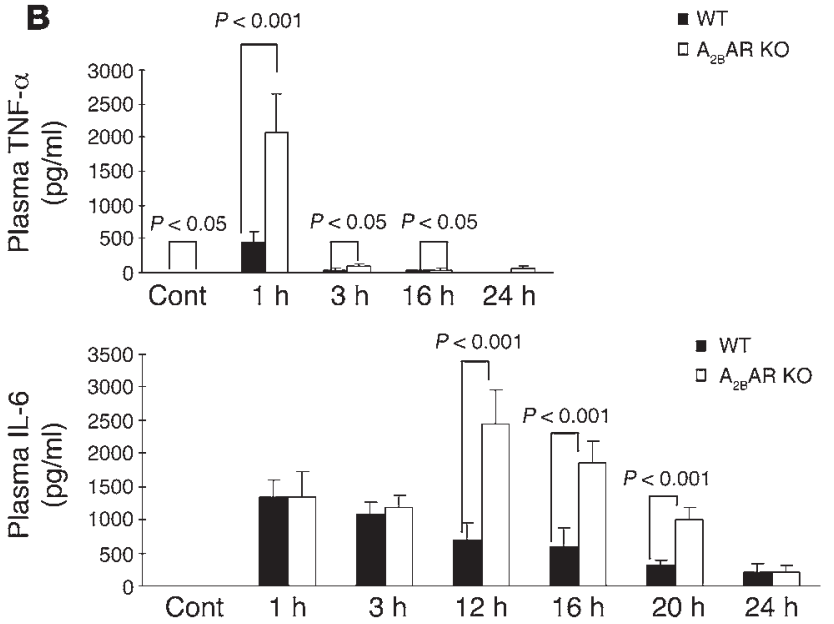

ᄃ $A_{28}$ AR KO
Cont

Figure 3

The levels of proinflammatory cytokines are increased in $\mathrm{A}_{2 \mathrm{~B}} \mathrm{AR}-\mathrm{KO}$ mice. (A) Basal levels of the indicated cytokines were measured in the liver of WT or KO mice. Results are presented as the average of 5 experiments \pm SD. (B) LPS-induced cytokine levels in the plasma of WT and $\mathrm{KO}$ mice. Mice were injected with LPS ( $5 \mu \mathrm{g} / \mathrm{g}$ body weight) or vehicle (control [Cont]), and at the indicated hours, plasma cytokine levels were determined. Data are presented as average \pm SD for 5 experiments performed in duplicate. TNF- $\alpha$ levels (pg/ml) in WT versus KO mice were $5.64 \pm 2.3$ versus $11.6 \pm 2.8$ at baseline; $51 \pm 19$ versus $106 \pm 34$ at 3 hours after LPS injection; $21 \pm 4$ versus $47 \pm 5.7$ at 16 hours after LPS injection; and $6.2 \pm 2.6$ versus $18 \pm 12$ at 24 hours after LPS injection. As to IL-6, the plasma levels (pg/ml) in WT and KO mice were $5.3 \pm 3.7$ and $5.1 \pm 3.8$, respectively. (C) For IL-10, the values $(\mathrm{pg} / \mathrm{ml}$ ) at baseline were $6.4 \pm 1.1 \mathrm{in} \mathrm{WT}$ mice and $7.2 \pm 1.5$ in $\mathrm{KO}$ mice. These relatively low levels are not illustrated clearly in the figure because of scale adjustment.

niently determined in various organs and specific cells within those organs. In all tissues tested, including colon, ovary, testis, liver, spleen, fat, muscle, pancreas, retina, brain, lung, heart, kidney, and arteries, the primary site of expression was the vasculature. In the brain and retina, however, there were also other cell types that expressed $\beta$-gal. Future studies will examine the exact identity and origin of cells expressing the receptor in these loci. Because of the significant $\beta$-gal staining in different vascular beds, our studies focused on the specific distribution of vascular $\mathrm{A}_{2 \mathrm{~B}} \mathrm{AR}$ expression (Figure $2 \mathrm{~A}$ ). The level of $A_{2 B} A R$ gene promoter-induced expression was different in various arteries tested, with the aortic arch, mesenteric artery, femoral artery, and small venules showing a high of level expression (Figure 2, A and B). Within these vessels, expression was evident in the VSMC layer, and to a lesser extent in endothelial cells, but not in the adventitia (Figure 2C and Supplemental Figure 2). Within the vascular smooth muscle layer, the expression was patchy (not all cells expressed the gene), particularly in the aortic arch (Supplemental Figure 2). The expression along the aorta was quite low and generally not detectable in most areas. A patchy expression in blood vessels was also reported for the $A_{3 A} A R$ gene promoter (36). It is intriguing to speculate that varying intensities of local signals within the vasculature induced by cytokines, sheer stress, and other factors affect the expression of the $A_{2 B} A R$ gene. This contention will be examined in future studies. In addition to blood vessels, $A_{2 B} A R$ gene promoter-directed expression was highly detected in macrophages (Figure 2D) but barely detectable in polymorphonuclear leukocytes (data not shown). This profile of expression was further supported by RT-PCR of RNA extracted from WT tissues (e.g., those shown in Figure 2A).
The $A_{2 B} A R$ controls proinflammatory cytokine production. In view of the significant expression of $\mathrm{A}_{2 \mathrm{~B}} \mathrm{AR}$ in macrophages, the effect of its deletion on the level of proinflammatory cytokines was examined. As shown in Figure 3A, basal levels of liver-derived TNF- $\alpha$ and IL-6 were approximately 2 -fold higher in $\mathrm{KO}$ compared with WT mice. Similar results were obtained with primary macrophages derived from these mice (Supplemental Figure 3), suggesting low-grade inflammation. To examine the response of these mice to challenge, they were stimulated with LPS. The level of serum TNF- $\alpha$ was 5 -fold higher in the KO mice compared with WT controls at 1 hour after LPS injection (Figure 3B). This observation is in accordance with the reported inhibitory effect of adenosine analogs on the release of TNF- $\alpha$ from macrophages via activation of $A_{2} A R s$ (37). This cytokine is rapidly (within an hour) and transiently elevated after exposure to endotoxin, while the increase in the other proinflammatory cytokine, IL-6, is sustained hours after LPS injection (34). The level of IL-6 was also greatly increased in $\mathrm{A}_{2 \mathrm{~B}} \mathrm{AR}-\mathrm{KO}$ mice treated with LPS compared with WT mice treated with this endotoxin, and this difference was manifested at 12 to 20 hours after injection. This suggests that IL-6 upregulation in LPStreated $\mathrm{A}_{2 \mathrm{~B}} \mathrm{AR}-\mathrm{KO}$ mice depends upon early signaling and changes induced during the first few hours after endotoxin injection. The extent of induction of the antiinflammatory cytokine IL-10 was reduced in the $\mathrm{KO}$ mice compared with WT (Figure $3 \mathrm{C}$ ). No change was observed in the level of IL-4 (data not shown). At 24-48 hours after LPS exposure, all plasma cytokine levels returned to basal levels in both control and $\mathrm{KO}$ mice.

$A_{2 B} A R$ deficiency enhances the expression of adhesion molecules as well as leukocyte adbesion and rolling. It has been shown that an increased level of circulating TNF- $\alpha$ is associated with the expression of 
A

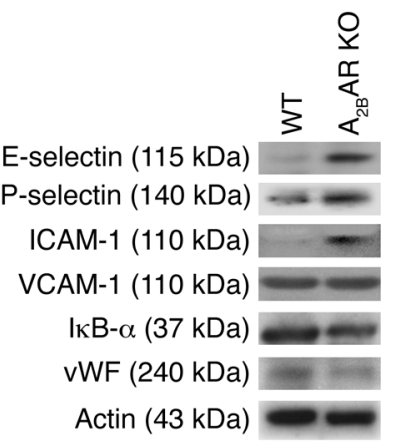

B

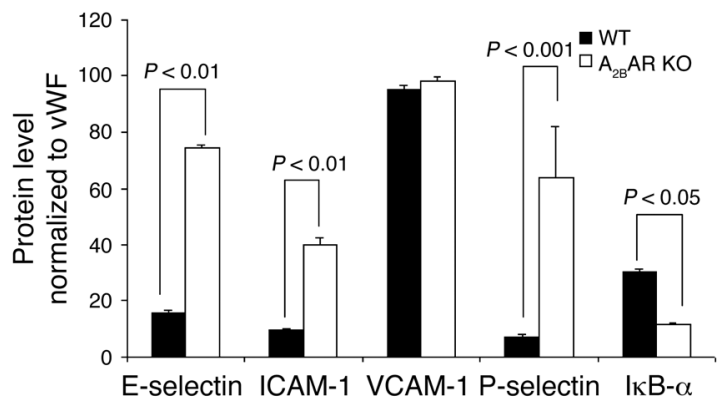

types, including VSMCs (29). Bone marrow transplantation experiments were conducted to examine the contribution of these cells to inflammatory cytokine production and to the induction of adhesion molecules in $\mathrm{A}_{2 \mathrm{~B}} \mathrm{AR}-\mathrm{KO}$ mice. Genotyping of sex chromosome-linked genes using PCR analysis was used to confirm cross-sex transplantation of bone marrow-derived cells (from male donor to female recipient) as described in Methods and shown in Figure 6A. Transplantation efficiency was determined by the percentage of $\beta$-gal-positive bone marrow macrophages in WT mice transplanted with $\mathrm{A}_{2 \mathrm{~B}} \mathrm{AR}-\mathrm{KO}$ mouse bone marrow cells (Figure 6B), and it was determined to be $97.5 \% \pm 6.9 \%(n=4)$. Red and white blood cell counts and platelet counts in all transplanted animals varied by up to $15 \%$ (data not shown). LPS-induced elevation of the proinflammatory cytokines TNF- $\alpha$ and IL- 6 in $\mathrm{KO} \rightarrow \mathrm{KO}$ (i.e., bone marrow from $\mathrm{A}_{2 \mathrm{~B}} \mathrm{AR}$-null mice transplanted into irradiated $\mathrm{A}_{2 \mathrm{~B}} \mathrm{AR}$-null mice) adhesion molecules in the vasculature $(38,39)$. Because basal levels of TNF- $\alpha$ were augmented in $\mathrm{A}_{2 \mathrm{~B}} \mathrm{AR}$-deficient mice, we examined adhesion molecule expression in $\mathrm{KO}$ versus WT mice. Interestingly, E-selectin, P-selectin, and ICAM-1 levels were all upregulated in $\mathrm{A}_{2 \mathrm{~B}} \mathrm{AR}$-deficient mice (Figure 4A). Previous studies demonstrated that the mechanism of adhesion molecule induction by TNF- $\alpha$ involves NF- $\kappa B$ activation, which depends on downregulation of the NF- $\kappa B$ inhibitor IкB- $\alpha$ (reviewed in refs. 40-42). Selectin upregulation in $\mathrm{KO}$ mice is accompanied by reduced IKB compared with WT mice (Figure 4B).

Induced expression of adhesion molecules is the underlying mechanism for leukocyte adhesion to blood vessels (43-45). For this reason, we sought to determine potential differences in leukocyte rolling and adhesion between WT and $\mathrm{A}_{2 \mathrm{~B}} \mathrm{AR}-\mathrm{KO}$ mice. These parameters were studied by intravital microscopy in 2 different types of mesenteric venules: large venules of 220-235 $\mu \mathrm{m}$ and microvenules of $25-35 \mu \mathrm{m}$ in diameter. Shear rates for all venules studied were similar in $\mathrm{A}_{2 \mathrm{~B}} \mathrm{AR}-\mathrm{KO}$ mice compared with WT mice (Supplemental Table 2). More leukocytes were observed rolling in $\mathrm{A}_{2 \mathrm{~B}} \mathrm{AR}-\mathrm{KO}$ mice compared with control mice (Figure 5A; $P<0.0001)$. We also found that leukocytes rolled at a slower velocity in $\mathrm{A}_{2 \mathrm{~B}} \mathrm{AR}-\mathrm{KO}$ mice. Of the total number of leukocytes analyzed for velocity, $65 \%$ rolled at a velocity of less than $20 \mu \mathrm{m} / \mathrm{s}$ in $\mathrm{A}_{2 \mathrm{~B}} \mathrm{AR}-\mathrm{KO}$ as compared with $23 \%$ in control mice (Figure $5 \mathrm{C}$ ). In addition, we observed that more leukocytes adhered to the endothelium at baseline conditions in $\mathrm{A}_{2 \mathrm{~B}} \mathrm{AR}-\mathrm{KO}$ compared with control samples (Figure 5A; $P<0.001$ ). Similar results were observed in the microvenules. More leukocytes rolled on the endothelium in $\mathrm{A}_{2 \mathrm{~B}} \mathrm{AR}-\mathrm{KO}$ compared with control mice (Figure $5 \mathrm{~B} ; P<0.005$ ), and more leukocyte adhesion to the endothelium was observed in the former line (Figure 5B; $P<0.05$ ). The leukocytes adhered to the endothelium for more than 25 seconds (Figure 5D).

Blood cell-derived signaling mediated by the $A_{2 B} A R$ induces cytokine release and adhesion molecule expression. Cytokines are produced by bone marrow-generated immune cells as well as by other cell

was about 3- to 5 -fold greater than LPS-induced levels in WT $\rightarrow$ WT (compare white bars in Figure 6C). In nontransplanted mice (Figure 3B), LPS induction of these cytokines was also 3- to 5-fold greater in KO mice compared with WT. As also shown in Figure 6C, after LPS treatment, TNF- $\alpha$ levels were greatly elevated in $\mathrm{KO} \rightarrow \mathrm{KO}$ and $\mathrm{KO} \rightarrow \mathrm{WT}$ mice compared with those in $\mathrm{WT} \rightarrow \mathrm{WT}$ mice or WT $\rightarrow$ KO. The level of IL- 6 followed a trend similar to that exhibited by TNF- $\alpha$, except that the induction in $\mathrm{KO} \rightarrow \mathrm{KO}$ was greater than in $\mathrm{KO} \rightarrow \mathrm{WT}$ (Figure $6 \mathrm{C}$ ). These results indicate that elevated TNF- $\alpha$ levels and a significant portion of IL- 6 originate from bone marrow-derived cells. In addition to macrophages, another known source of proinflammatory cytokines is VSMCs (29). We demonstrated that primary cultures of VSMCs and macrophages isolated from $\mathrm{A}_{2 \mathrm{~B}} \mathrm{AR}-\mathrm{KO}$ mice produced increased levels of TNF- $\alpha$ (in the case of macrophages) and IL- 6 (in the case of VSMCs and macrophages) under basal conditions and when exposed to LPS (in both cell types), compared with cultures derived from WT mice (Supplemental Figure 3). These results indicate that, at least under culture conditions (with mitogenic/serum stimuli), VSMCs produce greater levels of proinflammatory cytokines in the absence of $\mathrm{A}_{2 \mathrm{~B}} \mathrm{AR}$ expression compared with control. The effect of $\mathrm{A}_{2 \mathrm{~B}} \mathrm{AR}$ ablation on cytokine production was more prominent, however, in macrophages.

To examine whether selectin induction in the vasculature depends on signals from $\mathrm{A}_{2 \mathrm{~B}} \mathrm{AR}$-deleted bone marrow-derived cells, ICAM-1, P-selectin, and E-selectin were measured in the vasculature of transplanted mice. As shown in Supplemental Figure 4, KO mice implanted with WT mouse bone marrow cells showed decreased expression of adhesion proteins. This suggested that signals from bone marrow cells stimulate the expression of these proteins. The fold induction, however, was smaller than that in $\mathrm{KO}$ mice compared with WT mice (Figure 4B), suggesting that vascular $\mathrm{A}_{2 \mathrm{~B}} \mathrm{ARs}$ somewhat contribute to the observed upregulation.

Deletion of $A_{2 B} A R$ does not impact $B P$. Since the $A_{2 B} A R$ is highly expressed in the vasculature and because some studies implied 
A

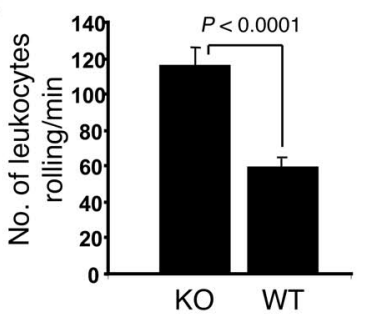

B

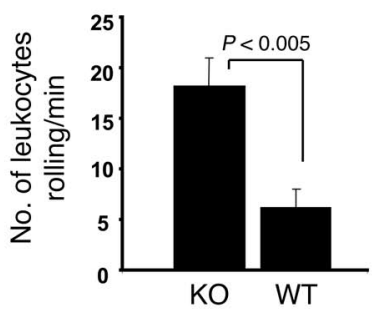

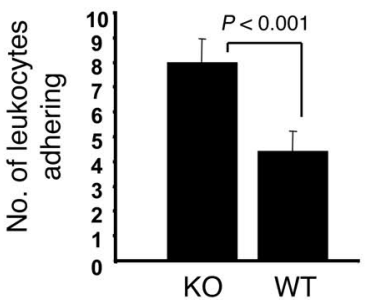

KO WT

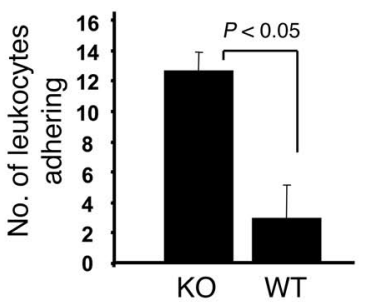

C

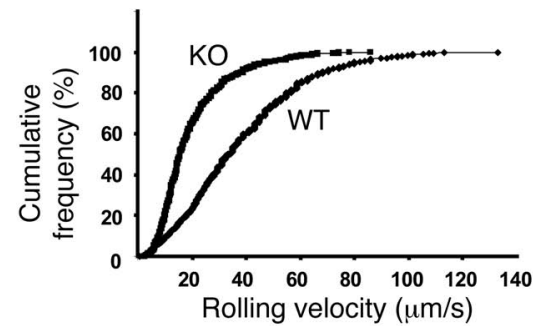

D
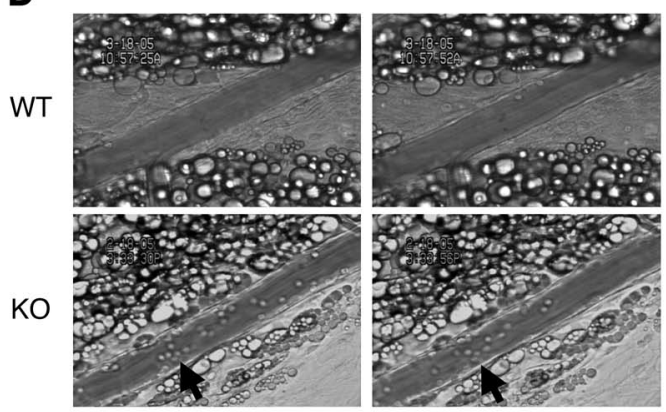

Figure 5

Analysis of basal leukocyte rolling and adhesion in mesenteric venules. Analysis of leukocyte rolling and adherence in venules of $220-235 \mathrm{um}$ in diameter (A) and 25-35 $\mu \mathrm{m}$ in diameter (B). Data shown are mean \pm SE for $8 \mathrm{KO}$ and 9 WT mice for venules of 220-235 $\mu \mathrm{m}$ in diameter and $5 \mathrm{KO}$ and $4 \mathrm{WT}$ mice for the 25- to 35- $\mathrm{mm}$-diameter microvenules. (C) Cumulative histogram of rolling velocities (venules of 220-235 $\mu \mathrm{m}$ in diameter) allows direct comparison of distribution among groups. The number of leukocytes analyzed for KO mice was 660 and for WT, 573 . $P<0.001$. (D) Photographs, taken 25 seconds apart, of the microvenules of WT and KO mice are shown. Arrows indicate adherent leukocytes.

its potential role in vascular tone $(25,26)$, we determined BP in the $\mathrm{A}_{2 \mathrm{~B}} \mathrm{AR}-\mathrm{KO}$ mice under basal conditions and in response to intravenous administration of adenosine at different concentrations. $\mathrm{A}_{2 \mathrm{~B}} \mathrm{AR}$ deficiency did not impact $\mathrm{BP}$ under basal conditions or after adenosine-induced vasodilation (Supplemental Figure 5 and Supplemental Table 3).

\section{Discussion}

Cell culture studies indicated that $A_{2 B} A R$ is expressed in immune cells, endothelial cells, and aortic vascular smooth muscle (reviewed in ref. 6). In addition to confirming the results of these previous reports, the $\mathrm{A}_{2 \mathrm{~B}} \mathrm{AR}-\mathrm{KO} /$ reporter gene-knockin mouse model showed that not all VSMCs express this gene. Our results demonstrated that the $A_{2 B} A R$ gene is differentially activated/suppressed in smooth muscle cells within different blood vessels. It is conceivable that varying intensities of local signals within vasculatures induced by cytokines, sheer stress, and other factors lead to differential expression of the $A_{2 B} A R$ gene in these loci. The underlying mechanism of this phenomenon awaits further investigation.

In comparison to other adenosine receptor subtypes, it was speculated that the $\mathrm{A}_{2 \mathrm{~A}} \mathrm{AR}$ is the most significant mediator of cytokine production (46). In a study using primary peritoneal macrophages (47), the potency of the $\mathrm{A}_{2 \mathrm{~A}} \mathrm{AR}$ selective agonist CGS 21680 in decreasing cytokine production indicated an effect on the $\mathrm{A}_{2 \mathrm{~A}} \mathrm{AR}$. Consistent with these findings, $\mathrm{A}_{2 \mathrm{~A}} \mathrm{AR}-\mathrm{KO}$ mice were reported to have increased levels of proinflammatory cytokines, albeit only upon challenge with LPS (24). The current study focuses attention on the $A_{2 B} A R$ as an important contributor to these phenomena. We found that the $A_{2 B} A R-K O$ mice displayed a mild but significant increase in proinflamma- tory cytokines under baseline conditions. Following a challenge with LPS, there was a large augmentation in production of these cytokines in the KO mice compared with WT controls. Intriguingly, at baseline, the $\mathrm{A}_{2 \mathrm{~B}} \mathrm{AR}-\mathrm{KO}$ mice showed upregulated levels of the adhesion molecules E-selectin, P-selectin, and ICAM-1 in the vasculature. Polymorphonuclear leukocytes are recruited into inflamed tissue via such adhesion molecules. Leukocyte rolling is supported by the endothelial selectins E-selectin and P-selectin (CD62E and CD62P), which are upregulated on the plasma membrane in response to cytokines $(48,49)$. In large venules as well as microvenules, more rolling of leukocytes and increased adhesion to the vessel were observed in the $\mathrm{A}_{2 \mathrm{~B}} \mathrm{AR}-\mathrm{KO}$ mice compared with control mice, pointing to an important role for this receptor in vascular homeostasis. Direct staining of at 10 aortic (along the aorta and in the arch) or mesenteric sections with antibodies against macrophage and leukocyte markers (using procedures described in Methods) showed no significant difference in $\mathrm{KO}$ versus WT tissues (data not shown). Although the $\mathrm{KO}$ mice exhibited inflammation, we did no necessarily expect accumulation of these cells within the tissue. Unless a chemoattractant is provided, such cells do not spontaneously transmigrate. As inflammation and increased leukocyte adhesion are known to aggravate atherosclerosis, it will be interesting to examine in the future the progression of this pathology in $\mathrm{A}_{2 \mathrm{~B}} \mathrm{AR}-\mathrm{KO}$ mice crossbred with apolipoprotein E-null mice, as the latter are known to provide a genetic background susceptible to atherosclerosis. Of interest, studies using $\mathrm{A}_{2 \mathrm{~A}} \mathrm{AR}-\mathrm{KO}$ mice showed no evidence of inflammation at baseline; however, inflammatory stimuli induced higher levels of proinflammatory cytokines in these $\mathrm{KO}$ mice than in WT mice, and the extent of induced liver injury was greater in the $\mathrm{KO}$ mice $(23,24)$. 
A

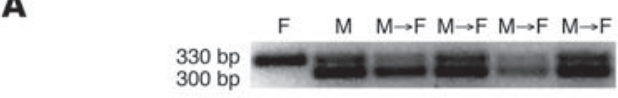

B

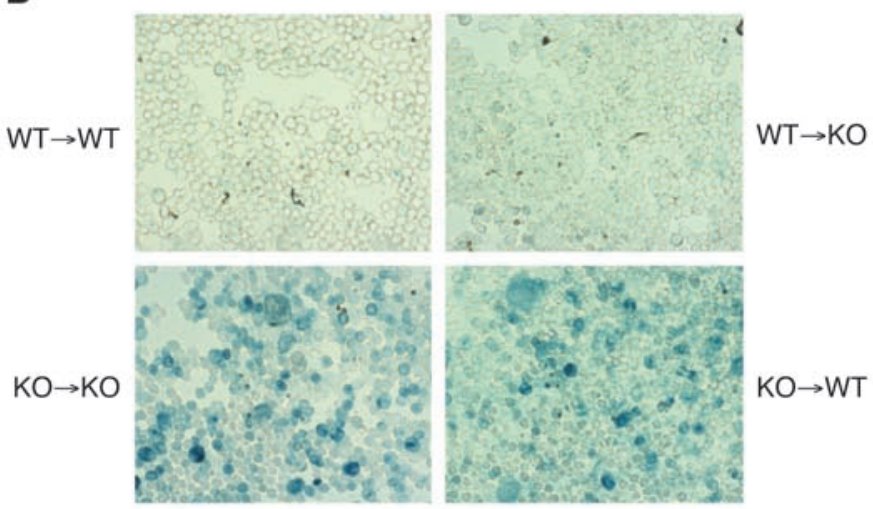

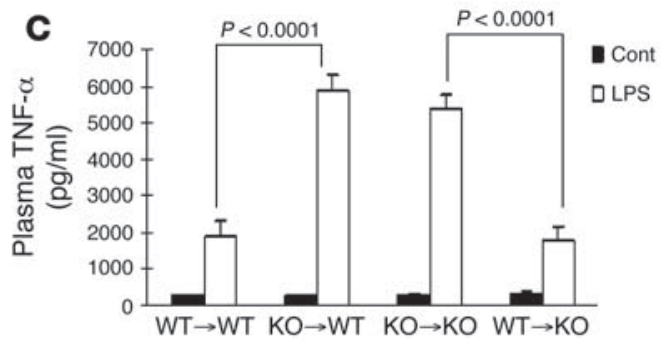

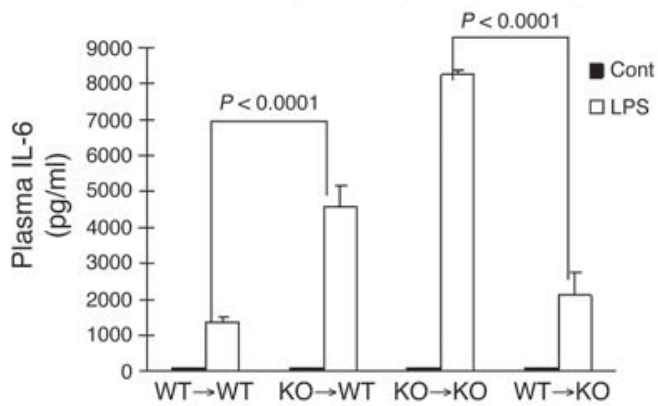

Figure 6

Signals derived from bone marrow cells enhance cytokine production and expression of adhesion molecules in $A_{2 B} A R$ KO mice. (A) PCR analysis of DNA from the transplanted mice, including males (M) to females (F), and expected PCR products, as detailed in Methods. (B) Under these conditions, the average efficiency of transplantation was assessed as $97.5 \% \pm 6.9 \%$ (SDs of 4 measurements) by monitoring the percentage of $\beta$-gal-positive KO peritoneal macrophages in transplanted WT mice (performed as in Figure 2D). This mode of assessment was possible since the total number of macrophages was similar in the different transplanted mice. (C) LPS-induced cytokine levels in the plasma. Mice were injected with vehicle (control) or LPS (5 $\mathrm{gg} / \mathrm{g}$ body weight), and plasma cytokine levels of TNF- $\alpha$ and of IL-6 were determined after 1 hour and 16 hours, respectively, following the elevation peaks noted in Figure 3B. Results are presented as average \pm SD of 4 experiments. In each case, bone marrow cells were derived from a genetic background (denoted on the left as WT or KO) and transplanted (denoted by an arrow) into a recipient (denoted on the right) (e.g., WT $\rightarrow$ WT). Similar results were obtained when mice were injected with $1 \mu \mathrm{g} / \mathrm{g}$ body weight LPS (data not shown).

Augmented levels of cytokines and adhesion molecules could be due to altered signaling in $\mathrm{A}_{2 \mathrm{~B}} \mathrm{AR}$-deleted vascular cells and/or due to activation by bone marrow cell-derived signals. Bone marrow transplantation studies indicated that bone marrow-derived $\mathrm{A}_{2 \mathrm{~B}} \mathrm{AR}$ signals induce cytokine elevation and upregulation of vascular adhesion molecules and suggest a role for the vascular $\mathrm{A}_{2 \mathrm{~B}} \mathrm{AR}$ as well. In accordance with these findings, primary cultures of aortic VSMCs derived from $\mathrm{A}_{2 \mathrm{~B}} \mathrm{AR}-\mathrm{KO}$ mice produced increased levels of IL- 6 under basal conditions and of IL- 6 and TNF- $\alpha$ in response to LPS, compared with cultures derived from matched control mice. Of note, bronchial smooth muscle cell $\mathrm{A}_{2 \mathrm{~B}} \mathrm{ARs}$ stimulate IL-6 production (29). In our study, elimination of the $\mathrm{A}_{2 \mathrm{~B}} \mathrm{AR}$ increased IL-6 production. The difference could be due to application of selective ligands in the former study, versus analysis of $\mathrm{KO}$ mice, and/or related to the source of the smooth muscle cells used.

Previous pharmacological studies have suggested a role for $\mathrm{A}_{2 \mathrm{~B}} \mathrm{AR}$ in determining $\mathrm{BP}(25,26)$. Studies with the $\mathrm{A}_{2 \mathrm{~B}} \mathrm{AR}-\mathrm{KO}$ mouse model, however, ruled out a role for this receptor in modulating $\mathrm{BP}$, under basal conditions and in response to adenosine. Furthermore, $\mathrm{A}_{2 \mathrm{~B}} \mathrm{AR}$ ablation did not affect the expression or activity of the $\mathrm{A}_{2 \mathrm{~A}} \mathrm{AR}$ (Supplemental Figure 1) or of other adenosine receptor subtypes (A1, A2a, and $\mathrm{A} 3$ ), which was determined by quantitative RT-PCR (data not shown). $\mathrm{A}_{2 \mathrm{~A}}$-deficient mice on a $\mathrm{CD} 1$ genetic background have increased $\mathrm{BP}$, heart rate, and platelet aggregation (15). $\mathrm{A}_{2 \mathrm{~A}}$-deficient mice on either a mixed 129-Steel $\times$ C57BL/6 (50) or congenic C57BL/6 (51) genetic background, however, did not display BP differences.
In summary, the study demonstrates the cell-specific anatomic location of endogenous $A_{2 B} A R$ gene expression and identifies the $\mathrm{A}_{2 \mathrm{~B}} \mathrm{AR}$ as a modulator of inflammatory cytokines, expression of adhesion molecules and of leukocyte adhesion, and rolling on blood vessels. Mechanisms related to altered expression of adhesion proteins in the $\mathrm{KO}$ mice involve IкB downregulation, primarily due to $A_{2 \mathrm{~B}} \mathrm{AR}$ signaling from bone marrow cells to the vasculature. The generation of $A_{2 B} A R$-deficient mice will also allow future examination of other $\mathrm{A}_{2 \mathrm{~B}} \mathrm{AR}$-dependent functions in different tissues. For example, $A_{2 B} A R$ is expressed in mast cells and may play an important role in the host response to inducers of asthma (reviewed in ref. 52). Similarly, the significance of $A_{2 B} A R$ expression in the brain and retina await future investigation.

\section{Methods}

\section{Generation of $A_{2 B} A R-K O / \beta$-gal-knock-in mice}

The mouse $A_{2 B} A R$ gene (GenBank accession number AL596110) was cloned from a mouse ES-129/SvJ bacterial artificial chromosome library, and the $A_{2 B} A R$ gene structure is shown in Figure 1A. The targeting vector, $\mathrm{A}_{2 \mathrm{~B}} \mathrm{AR}$-KO- $\beta$-gal was constructed as depicted in Figure 1A. A strategy was employed to delete exon 1 , including the initiation codon, and to introduce instead a reporter gene with a stop codon and poly(A) at the $3^{\prime}$ end to terminate transcription. Exon 1 in the $A_{2 B} A R$ gene encodes 3 transmembrane domains of $\mathrm{A}_{2 \mathrm{~B}} \mathrm{AR}$ (53), and deleting it will remove the initiation methionine. The next in-frame methionine is not present until the fifth transmembrane domain (past the ligand-binding domain) (53). Hence, even if transcription is unexpectedly initiated past the transcrip- 
tion termination signal of the reporter gene, the truncated protein formed is not likely to fold or to be functional, as it will not bind a ligand. To confirm this contention, mRNA expression and functional studies were pursued as detailed below. Also of note, there are no annotated $\mathrm{A}_{2 \mathrm{~B}} \mathrm{AR}$ pseudogenes in the mouse genome listed at the NCBI Nucleotide database (http://www.ncbi.nlm.nih.gov/entrez/query.fcgi?db=Nucleotide) or potential unknown pseudogenes, based on using the Basic Local Alignment Search Tool (BLAST; http://www.ncbi.nlm.nih.gov/genome/seq/ BlastGen/BlastGen.cgi?taxid=10090) under permissive conditions. The human $A_{2 B} A R$ pseudogene (GenBank accession number NG_000843) is typical of a retrotransposed pseudogene, meaning that it does not contain introns or the promoter (mRNA was reverse transcribed and then inserted in the genome). This type of pseudogene would not be targeted by our construct, because the flanking homologous regions are those of the promoter and the intron. To generate the targeting vector, a $3.6-\mathrm{kb}$ fragment from intron 1 of the $A_{2 B} A R$ gene generated by KpnI/XhoI endonuclease restriction digestion was first subcloned into a pPNT vector at KpnI/ EcoRI sites between the neomycin (Neo) gene cassette and thymidine kinase (TK) cassette using a XhoI-EcoRI linker, yielding PPNT- $\mathrm{A}_{2 \mathrm{~B}} \mathrm{AR}-$ intron. A $6-\mathrm{kb}$ fragment of the $A_{2 B} A R$ gene promoter was subcloned into the $5^{\prime}$ end of the gene encoding prokaryotic $\beta$-gal in the pBS-lacZ plasmid. The 9.4-kb NotI/XhoI $\mathrm{A}_{2 \mathrm{~B}} \mathrm{AR}-\beta$-gal fragment was then subcloned into pPNT- $\mathrm{A}_{2 \mathrm{~B}} \mathrm{AR}$-intron at the NotI/XhoI sites, $5^{\prime}$ of the Neo cassette. Recombinant $\mathrm{A}_{2 \mathrm{~B}} \mathrm{AR}$-KO-LacZ ES cells (mouse 129/SvJ derived) were obtained and cultured according to conventional methods (e.g., ref. 15). The positive recombinant ES colonies were first screened with Extend Long PCR (Roche Diagnostics), using the primer pair sense 5'-CAGCCTCTGTTCCACATACACTTCA-3' and antisense 5'-AGCAGGGACTGGAAAGGTAGGTATT-3, yielding a 4-kb amplicon. The positively identified $A_{2 B} A R-$ KO- $\beta$-gal ES cell clone 23 was injected into C57BL/6-derived blastocysts, which were subsequently implanted back into FVB foster mothers. Positive chimeric mouse lines were identified by coat color, and their offspring was screened by PCR and Southern blot analysis of tail DNA. PCR WT upstream primer 5'-CTCACACAGAGCTCCATCTT-3' and downstream primer 5'-TCTGGCAGCAGCTTTGAT-3' were used to produce a 485-bp fragment (both primers are located in the intron 1 area). Mutant upstream primer 5'-CAGCCTCTGTTCCACATACACT-3' and downstream primer 5'-GGCACCTCTCCCTCCAAGACAC-3' were used to generate a 900-bp fragment (both primers are located in the Neo cassette). The heterozygous mice were backcrossed to $\mathrm{C} 57 \mathrm{BL} / 6 \mathrm{~J}$ strain mice for 4 generations to generate congenic $\mathrm{C} 57 \mathrm{BL} / 6 \mathrm{~J}$ strain $A_{2 B} A R$ gene mutant mice. In this study, the mice used were of $80 \% \mathrm{C} 57 \mathrm{BL} / 6 \mathrm{~J}$ background strain, confirmed by the PCR-based gene marker analysis MAX-BAX (Charles River Laboratories). Crossbreeding of the $80 \% \mathrm{C} 57 \mathrm{BL} / 6 \mathrm{~J}$ strain $\mathrm{A}_{2 \mathrm{~B}} \mathrm{AR}$ mutant heterozygous mice generated the same background strain as WT or $A_{2 B} A R$ gene-KO homozygous mice. In the experiments shown, control and knockout mice were strain-, sex-, and age-matched (8-12 weeks old unless otherwise indicated). All procedures were performed according to the Guidelines for Care and Use of Laboratory Animals published by the NIH. Throughout this study, all animals received humane care that was in agreement with the guidelines of and approved by the Institutional Animal Care and Use Committee of the Boston University School of Medicine. All analyses were repeated $(n)$ to obtain averages \pm SDs and subjected to 2-tailed Student's $t$ tests, as indicated in each figure. $P$ values less than 0.05 were considered statistically significant.

\section{Measurement of $A_{2 B} A R$ expression and activity in different tissues and cells, including smootb muscle cells and macrophages}

Total RNA from different mouse tissues was prepared with TRIzOL (according to the manufacturer's protocol; Invitrogen). RT-PCR was used ( $1 \mu \mathrm{g}$ RNA, Moloney murine leukemia virus [M-MLV] reverse transcriptase, $1 \times$ first-strand buffer, $0.5 \mathrm{mM}$ dNTP, $5 \mathrm{mM}$ DTT, $0.5 \mathrm{U} / \mu \mathrm{l}$ RNase inhibitor, $5 \mu \mathrm{M}$ random primers, all purchased from Invitrogen) to measure $\mathrm{A}_{2 \mathrm{~B}} \mathrm{AR}$ mRNA expression. RNA was treated with RQ1 RNaseFree DNase (according to the manufacturer's instructions; Promega, catalog no. M6101) and this was followed by RT-PCR performed in the presence or absence of reverse transcriptase $(1 \mu \mathrm{g}$ RNA, M-MLV reverse transcriptase, $1 \times$ first-strand buffer, $0.5 \mathrm{mM}$ dNTP, $5 \mathrm{mM} \mathrm{DTT}, 0.5 \mathrm{U} / \mu \mathrm{l}$ RNase inhibitor, $5 \mu \mathrm{M}$ random primers, all purchased from Invitrogen). The primer pairs were designed to produce a 746-bp fragment within exon 1 (PCR primers: sense, 5'-ATGCAGCTAGAGACGCAAGA-3'; antisense, 5'-GGAGCCAACACACAGAGCAA-3'). To optimally detect $\mathrm{A}_{2 \mathrm{~B}} \mathrm{AR}$ mRNA, the number of PCR cycles in our system was set at 30 . GAPDH mRNA expression, used as control, was set at 20 cycles (GAPDH primers generate 554-bp fragments and were: sense, $5^{\prime}$-TCACCATCTTCCAGGAG-3' and antisense, 5'-GCTTCACCACCTTCTTG-3'). To amplify the second exon in $\mathrm{A}_{2 \mathrm{~B}} \mathrm{AR}$ cDNA by RT-PCR, the following primers were employed: sense, 5'-CAAGTGGGTGATGAATGTGG-3'; antisense- 5' TTTCCGGAATCAATTCAAGC-3' (to generate a 448-bp fragment). The primers were selected using Primer3 primer design tool (http:// frodo.wi.mit.edu/cgi-bin/primer3/primer3_www.cgi). The MacVector sequence alignment program (version 6.5.3; Accelrys) was used to ensure that the homology to $\mathrm{A}_{2 \mathrm{~A}} \mathrm{AR}, \mathrm{A}_{1} \mathrm{AR}$, or $\mathrm{A}_{3} \mathrm{AR}$ was no greater than $75 \%$ (50\% in most areas), with little homology at primer ends. Aberrant fragments potentially generated from other adenosine receptors will be of a different size than amplified $\mathrm{A}_{2 \mathrm{~B}} \mathrm{AR}$ exon 2 (see Supplemental Figure 1A). Additionally, primers were analyzed using UCSC Genome Bioinformatics In-Silico PCR tool (http://genome.ucsc.edu/cgi-bin/ hgPcr?command=start) to ensure that there was no amplification of other gene sequences. Total RNA was isolated from mesenteric artery or kidney by immediate homogenization in TRIzol reagent (Invitrogen) or using Versagene RNA Tissue Kit according to the manufacture's protocol (Gentra). RNA was treated with DNase I (Promega) for 30 minutes at $37^{\circ} \mathrm{C}$ prior to reverse transcription consisting of $1 \mu \mathrm{g}$ RNA, M-MLV reverse transcriptase, $1 \times$ first-strand buffer, $0.5 \mathrm{mM}$ dNTP, $5 \mathrm{mM}$ DTT, $0.5 \mathrm{U} / \mu \mathrm{l}$ RNase inhibitor, $5 \mu \mathrm{M}$ random primers (all purchased from Invitrogen). A mock reaction lacing reverse transcriptase served as a control for DNA contamination. RT-PCR of exon 2 was performed with the above-mentioned primers with a program of 1 cycle at $95^{\circ} \mathrm{C}$ for 2 minutes, 30 cycles at $95^{\circ} \mathrm{C}$ for 55 seconds, $60^{\circ} \mathrm{C}$ for 55 seconds, $72^{\circ} \mathrm{C}$ for 55 seconds, and 1 cycle at $72^{\circ} \mathrm{C}$ for 5 minutes.

VSMCs were isolated from aortas of 6-week-old WT or $A_{2 B} A R-K O$ mice by enzymatic dispersion as previously described (54). Eighteen hours after seeding, VSMC culturing media was removed and replenished with $100 \mu \mathrm{l} /$ well of fresh VSMC culturing media containing $5 \mu \mathrm{M}$ MRS1754 [8-(4-[\{(4-cyanophenyl)carbamoylmethyl $\}$ oxy]phenyl)1,3-di(n-propyl)xanthine; Sigma-Aldrich, catalog no. M-6316]. After a 10 -minute pretreatment, cells were stimulated by adding $5 \mu \mathrm{M}$ NECA (Sigma-Aldrich) or $5 \mu \mathrm{M}$ forskolin ( $7 \beta$-acetoxy- $1 \alpha, 6 \beta, 9 \alpha$-trihydroxy8,13-epoxy-labd-14-en-11-one; Sigma-Aldrich) for another 10 minutes. cAMP levels in VSMCs were measured using cAMP-Screen Chemiluminescent Immunoassay for Determination of cAMP Concentration Kit (Applied Biosystems, catalog no. T1500). Similar cAMP experiments were pursued using peritoneal macrophages. Mice were injected with $50 \mathrm{ml} / \mathrm{kg}$ Brewer thioglycollate medium (Sigma-Aldrich, catalog no. B 2551), and peritoneal macrophages were collected 3 days after injection. Cells were plated in 24 -well plates $\left(10^{6}\right.$ cells/well $)$ and cultured overnight. After pretreatment with $5 \mu \mathrm{M}$ MRS1754 for 10 minutes, cells were stimulated by adding $5 \mu \mathrm{M}$ NECA or $1 \mu \mathrm{M}$ CGS 21680 hydrochloride (Tocris Bioscience, catalog no. 1063) for another 10 minutes. 
cAMP levels were measured using Direct Cyclic AMP Kit (Assay Designs, catalog no. 900-066).

\section{Primers used to amplify all adenosine receptor $m R N A s$ by PCR} RNA preparation and PCR conditions were essentially as listed above for the $A_{2 B} A R$. For the $A_{1 A} A R$, the primers used were: sense, 5'-GCTTAGTCCCTCAGAATCACG-3'; antisense, 5'-CCCTTGTCCTTAGAGGTTCCA-3'; expected fragment of $436 \mathrm{bp}$. For the $\mathrm{A}_{2 \mathrm{~A}} \mathrm{AR}$, the primers were: sense, 5'-TGAAGGCGAAGGGCATCA-3'; antisense, 5'-CGCAGGTCTTTGTGGAGTTCT-3'; expected fragment of 117 bp. For the $\mathrm{A}_{3 \mathrm{~A}} \mathrm{AR}$, the primers were: sense, 5'-TAATGGGAAGGCAGGGATAAG-3'; antisense, 5'-GATGTAGGTGATGTTCAGCCA-3'; expected fragment of $284 \mathrm{bp}$. The PCR conditions included: 1 cycle at $95^{\circ} \mathrm{C}$ for 2 minutes, $95^{\circ} \mathrm{C}$ for 50 seconds, $60^{\circ} \mathrm{C}$ for 50 seconds, $72^{\circ} \mathrm{C}$ for 50 seconds, for 28 or 30 cycles, and 1 cycle of 5 minutes at $72^{\circ} \mathrm{C}$.

\section{Analysis of $\beta$-gal expression in tissue sections and in cells}

$\beta$-gal assay in tissue sections at the light-microscopic level. Mice were anesthetized with isoflurane and perfused through the left heart ventricle with $20 \mathrm{ml}$ PBS ( $\mathrm{pH} 7.4)$ at a rate of $4 \mathrm{ml} / \mathrm{min}$. Perfusion with fixative $(30 \mathrm{ml}$ freshly made $2 \%$ paraformaldehyde in PBS [pH 7.4]) continued for 15 minutes at $2 \mathrm{ml} / \mathrm{min}$, followed by perfusion with PBS for 10 minutes. Various tissues were dissected from the perfused mouse and stored in ice-cold $\mathrm{PBS}$, prior to staining for $\beta$-gal activity. Individual organs were cut into 1- to 2 -mm-thick slices and stained with $\mathrm{X}$-gal staining solution $[5 \mathrm{mM}$ $\mathrm{K}_{3} \mathrm{Fe}(\mathrm{CN})_{6}, 5 \mathrm{mM} \mathrm{K}_{4} \mathrm{Fe}(\mathrm{CN})_{6} \cdot 3 \mathrm{H}_{2} \mathrm{O}$ (Sigma-Aldrich, catalogue nos. P-8131 and P-9287, respectively), $2 \mathrm{mM} \mathrm{MgCl}$, in PBS] containing a final concentration of $1 \mathrm{mg} / \mathrm{ml}$ 5-bromo-4-chloro-3-indolyl- $\beta$-D-galactopyranoside (X-gal; American Bioanalytical, catalog no. AB02400-1000) or halogenated indolyl- $\beta$-D-galactoside, as indicated (Bluo-gal; Sigma-Aldrich, catalog no. B2904). Samples were incubated at $37^{\circ} \mathrm{C}$ for $6-12$ hours on a rocking platform. After staining, samples were rinsed with PBS and stored in $4 \%$ paraformaldehyde at $4^{\circ} \mathrm{C}$. Samples were embedded in paraffin and cut at a thickness of $5 \mu \mathrm{m}$. Sections were stained with H\&E.

Analysis of $\beta$-gal expression at the ultrastructural level. Mouse tissue was stained for $\beta$-gal activity as described above, except that Bluo-gal (halogenated indolyl- $\beta$-D-galactoside from Invitrogen; catalog no. 15519-010) was used as a substrate instead of X-gal. Tissues were processed for electron microscopy using a modification of a previously published protocol (36). Briefly, 25\% glutaraldehyde (Polysciences Inc.) was diluted to $4.3 \%$ with $0.03 \mathrm{M}$ sodium barbital-sodium acetate buffer ( $\mathrm{pH} 7.4$ ) in $0.07 \mathrm{M}$ potassium chloride. The samples were kept in this glutaraldehyde solution overnight at $4{ }^{\circ} \mathrm{C}$. The samples were rinsed 3 times with sodium barbital-sodium acetate buffer containing potassium chloride for 15 minutes each. This was followed by dehydration in a graded series of ethanol starting with 50\% ethanol, embedded in a 1:1 mixture of Araldite 502 (Ted Pella Inc.) and dodecenyl succinic anhydride at $60^{\circ} \mathrm{C}$. After polymerization of the Araldite mixture, sections were cut on an LKB Ultratome V. Ribbons of sections showing gray, silver, or slightly gold interference colors were picked up on uncoated 200-mesh Athene Thin Bar copper grids.

$\beta$-gal assay in macrophages, polymorphonuclear cells, and bone marrow cells. Peritoneal macrophages were collected from 6-week-old WT or $\mathrm{A}_{2 \mathrm{~B}} \mathrm{AR}$ $\mathrm{KO}$ mice (4 mice per group). To this end, mice were anesthetized by inhalation of isoflurane and then injected with PBS $(5 \mathrm{ml} / \mathrm{mouse})$ in the peritoneal cavities. After 5 minutes of massaging, injected PBS was collected from the peritoneal cavities and spun down at $800 \mathrm{~g}$, for 10 minutes, at $4^{\circ} \mathrm{C}$. Red cells were lysed with $8 \mathrm{ml}$ of prewarmed lysis buffer $(17 \mathrm{mM}$ Tris, $140 \mathrm{mM} \mathrm{NH}_{4} \mathrm{Cl}$ in $\mathrm{H}_{2} \mathrm{O}$, pH 7.2) at $37^{\circ} \mathrm{C}$, for exactly 10 minutes. Cell pellets were washed and centrifuged in $10 \mathrm{ml}$ PBS twice. Cells were resuspended in $1 \mathrm{ml} /$ well serum-free RPMI (RPMI-1640 medium supple- mented with $4 \mathrm{mM}$ L-glutamine, $50 \mu \mathrm{M} 2$-mercaptoethanol, $1 \mathrm{mM}$ sodium pyruvate, $100 \mathrm{U} / \mathrm{ml}$ penicillin, $100 \mu \mathrm{g} / \mathrm{ml}$ streptomycin, and $0.1 \mathrm{mM}$ nonessential amino acids) and seeded on a 24-well plate. After 3 hours of incubation at $37^{\circ} \mathrm{C}$ and $5 \% \mathrm{CO}_{2}$, the media with nonadherent cells (nonmacrophages, polymorphonuclear cells) were removed. Attached macrophages were rinsed with PBS twice and fixed with $0.5 \%$ glutaraldehyde (Sigma-Aldrich, catalog no. G-7651) in PBS for 10 minutes at room temperature. Macrophages were then rinsed 2 times with $\mathrm{PBS}$ and stained in X-gal solution $\left[4 \mathrm{mM} \mathrm{K}_{4} \mathrm{Fe}(\mathrm{CN})_{6} \cdot 3 \mathrm{H}_{2} \mathrm{O}, 4 \mathrm{mM} \mathrm{K}_{3} \mathrm{Fe}(\mathrm{CN})_{6}, 1 \mathrm{mM}\right.$ $\mathrm{MgCl}_{2}, 1 \mathrm{mg} / \mathrm{ml} \mathrm{X}$-gal in PBS] for 7 hours at $37^{\circ} \mathrm{C}$. Bone marrow cells were isolated from the femurs of 6-week-old WT or $\mathrm{A}_{2 \mathrm{~B}} \mathrm{AR}-\mathrm{KO}$ mice as described previously (55). Cell pellets were resuspended in fixative buffer for 20 minutes ( $0.5 \%$ glutaraldehyde, $0.02 \%$ Nonidet P-40 [NP-40] in $1 \times \mathrm{PBS}$ without $\mathrm{MgCl}_{2}$ ), washed twice with PBS, and then incubated in 1 $\mathrm{ml} \mathrm{X}$-gal staining solution for $16-20$ hours at $37^{\circ} \mathrm{C}$. Cells were mounted onto slides, and blue precipitates (indicative of $\beta$-gal activities) were visualized via light microscopy.

\section{Cytokine measurements in plasma and in liver}

eBioscience ELISA Ready-SET-Go! kits testing for mouse TNF- $\alpha$ (catalog no. 88-7324-22), IL-6 (catalog no. 88-7064-22), IL-10 (catalog no. 88-7104-22), IL-2 (catalog no. 88-7024-22), IL-4 (catalog no. 88-7044-22), and IFN- $\gamma$ (catalog no. 88-7314-22) were used to measure cytokine levels in plasma and in liver according to the manufacturer's protocol. Liver protein was extracted as described in "Western blot analysis" below.

\section{Blood cell count}

Blood was harvested and blood cells were counted as we have described elsewhere $(56,57)$.

\section{Western blot analysis}

Tissues were homogenized and lysed on ice with radioimmunoprecipitation assay (RIPA) buffer ( $1 \times$ PBS, $1 \%$ NP-40, $0.5 \%$ sodium deoxycholate, $0.1 \% \mathrm{SDS}, 10 \mathrm{mg} / \mathrm{ml}$ PMSF, and aprotinin $[2 \mu \mathrm{g} / \mathrm{ml}]$ freshly supplemented with $1 \times$ protease inhibitor cocktail (Roche Diagnostics). Lysates were vigorously vortexed and incubated on ice for 30 minutes, then frozen in liquid nitrogen and thawed at $37^{\circ} \mathrm{C}$. Finally, lysates were cleared by centrifugation at $800 \mathrm{~g}$ for 10 minutes at $4^{\circ} \mathrm{C}$. Fifty micrograms/sample of total protein was electrophoresed on $6 \%$ or $10 \%$ SDS-PAGE gels and transferred overnight at $4{ }^{\circ} \mathrm{C}$ to Immobilon-P PVDF membranes (Millipore), and Western blotting was performed as described in ref. 58. The following antibodies (purchased from Santa Cruz Biotechnology Inc.) were used: rabbit polyclonal anti-E-selectin antibody (1:200 dilution; catalog no. sc-14011), goat polyclonal anti-vWF antibody (1:200 dilution; catalog no. sc-8068), rabbit polyclonal anti-ICAM-1 antibody (1:200 dilution; catalog no. sc-1511), mouse monoclonal anti-VCAM1 antibody (1:1,000 dilution; catalog no. sc-13506), goat polyclonal anti-P-selectin antibody (1:200 dilution; catalog no. sc-6943), rabbit polyclonal anti-IкB- $\alpha$ antibody (1:1,000 dilution; catalog no. sc-371), mouse monoclonal anti-actin antibody (1:1,000 dilution; catalog no. sc1616). Secondary antibodies included: goat anti-rabbit IgG-HRP (catalog no. sc-2004), donkey anti-goat IgG-HRP (catalog no. sc-2056), and goat anti-mouse IgG-HRP (catalog no. sc-2005).

\section{Immunohistochemistry of macrophages and leukocytes in aortic and mesenteric tissue sections}

Tissues were collected after fixation as described for $\beta$-gal staining. They were embedded with paraffin and cut at a thickness of $5 \mu \mathrm{m}$. After deparaffinization, rehydration and high-temperature antigen retrieval were performed as follows. Sections were placed in $10 \mathrm{mM}$ citric acid, $\mathrm{pH} 6$, and 
heated by 700 -W microwave for 2 minutes 3 times, with 2-minute intervals between each time, followed by cooling down for 20 minutes. Paraffin sections were blocked with $10 \%$ normal goat serum (Vector Laboratories, cata$\log$ no. S-1000) for 1 hour at $37^{\circ} \mathrm{C}$ and then incubated overnight at $4^{\circ} \mathrm{C}$ with rat anti-mouse CD43 monoclonal antibody diluted 1:25 (BD Biosciences, catalog no. 552366) to detect leukocytes or with rat anti-mouse F4/80 monoclonal antibody (Serotec, catalog no. MCA497R) to detect macrophages. The staining was revealed using goat anti-rat biotinylated secondary antibody (Vector Laboratories, catalog no. BA-9400) at a dilution of 1:200 with an incubation time of 1 hour at $37^{\circ} \mathrm{C}$. After $1 \times \mathrm{PBS}$ wash, sections were incubated with $\mathrm{ABC}$ reagent (Vector Laboratories, catalog no. PK-6100) for 30 minutes at $37^{\circ} \mathrm{C}$, and Vector DAB substrate (Vector Laboratories, catalog no. SK-4100) was used to develop the brown positive signal by incubating the sections for 5 minutes. Sections were counterstained with Shandon Gill 3 Hematoxylin (Thermo Electron Corp., catalog no. 6775009).

\section{LPS-induced acute inflammation}

WT or $\mathrm{A}_{2 \mathrm{~B}} \mathrm{AR}-\mathrm{KO}$ mice were given a single i.p. injection of LPS (E. coli serotype 0127:B8; Sigma-Aldrich, catalog no. L-4516) at $5 \mu \mathrm{g} / \mathrm{g}$ of body weight or of saline in a total volume of up to $100 \mu \mathrm{l}$ (control). Mice were sacrificed at 1 hour, 3 hours, 16 hours, and 24 hours after LPS or saline administration and subjected to blood and tissue collection. Plasma and liver protein were used for cytokine measurements.

\section{Bone marrow transplantation experiments}

Generation of chimeric mice by bone marrow transplantation. Ten-week-old WT or $\mathrm{A}_{2 \mathrm{~B}} \mathrm{AR}-\mathrm{KO}$ female mice were irradiated with a total dose of $12.5 \mathrm{~Gy}$ from a ${ }^{137} \mathrm{Cs}$ source (34). On the day of irradiation, bone marrow cells were harvested from 10-week-old WT or $\mathrm{A}_{2 \mathrm{~B}} \mathrm{AR}$-KO male donor mice femurs. The bone marrow cells were subjected to red blood cell lysis, as described previously (55), and injected into irradiated mice at a dose of $2 \times 10^{6}$ cells/recipient in $0.3 \mathrm{ml}$ through the tail vein. Five weeks after irradiation, peripheral blood was collected via the retro-orbital sinus and prepared for blood DNA isolation (Gentra VERSAGENE DNA Blood Kits, catalog no. VGD-0050B1).

Determination of repopulation efficiency of bone marrow-derived cells in chimeric mice. Genotyping of sex chromosome-linked genes (Jaridld and Jaridlc) was used to confirm cross-sex transplantation of bone marrow-derived cells (from male donor to female recipient) as reported before. Jaridld and Jaridlc PCR upstream primer 5'-CCGCTGCCAAATTCTTTGG-3' and downstream primer 5'-TGAAGCTTTTGGCTTTGAG-3' were used to produce a $300-\mathrm{bp}$ fragment in female mice and both 300-bp and 330-bp fragments in male mice. Six weeks after transplantation, bone marrow cells were isolated from the femurs of all 4 groups of mice (WT $\rightarrow \mathrm{WT}, \mathrm{KO} \rightarrow \mathrm{WT}, \mathrm{KO} \rightarrow \mathrm{KO}, \mathrm{WT} \rightarrow \mathrm{KO}$ ) and used for $\beta$-gal staining according to the method described above. For each group, $\beta$-gal-positive (blue) cells were counted under microscopy in randomly chosen fields (with native $\mathrm{A}_{2 \mathrm{~B}} \mathrm{AR}-\mathrm{KO}$ and WT mice as controls). To further test the efficiency of transplantation under our protocol, bone marrow cells from GFP mice (Jackson Laboratory, strain name C57BL/6$\mathrm{Tg}$ [UBC-GFP] 30Scha/J, stock no. 004353) were transplanted into WT or $\mathrm{A}_{2 \mathrm{~B}} \mathrm{AR}-\mathrm{KO}$ mice, which we used as transplant recipients. Six weeks after transplantation, bone marrow cells were isolated from recipients and mounted on slides. GFP-positive cells were counted under a fluorescence microscope with GFP transgenic mice and WT mice as controls (data not shown).

Sample collection from transplant-recipient chimeric mice and related assays. Six weeks after transplantation, chimeric mice were injected i.p. with $1 \mu \mathrm{g} / \mathrm{g}$ or $5 \mu \mathrm{g} / \mathrm{g}$ body weight of LPS. Blood and liver samples were collected at 0 hours, 1 hour, and 16 hours after LPS injection. Plasma was used for cytokine measurements as we described above. Proteins were also subjected to Western blot analysis, and blood cell count was determined, all as described above.

\section{Tail-cuff and direct BP measurements, adenosine infusion- catheterization, and determination of heart rates}

Tail-cuff systolic BP was obtained at baseline using a computerized tailcuff system (BP 2000, Visitech Systems) as described in ref. 59. Arterial and venous catheterization was performed under anesthesia induced by sodium pentobarbital (50 mg/kg, i.p.) (60). A modified polyethylene catheter (PE-50) was introduced into the right iliac artery for direct $\mathrm{BP}$ recording, and silastic tubing was placed into the right iliac vein for adenosine infusion. Both catheters were tunneled subcutaneously and exteriorized at the back of the animal's neck. Subsequently, they were filled with heparin in $0.9 \%$ saline solution, sealed with heat, and attached to the animal's nape. After the surgery, the animals were returned to their cages and allowed an overnight recovery period. On the following day, the arterial catheter was connected to a BP transducer attached to a recorder (model 220S; Gould) for direct $\mathrm{BP}$ monitoring. Control BP was recorded for no less than $30 \mathrm{~min}-$ utes, when the BP became stable. The venous catheter was connected to a Harvard infusion pump (Harvard Apparatus), and adenosine was administered at a dose of $200-600 \mu \mathrm{g} / \mathrm{kg} / \mathrm{min}$ for 60 minutes. Heart rates were measured as described previously (13).

\section{Analysis of leukocyte rolling by intravital microscopy}

Mice were anesthetized with $2.5 \%$ tribromoethanol $(0.15 \mathrm{ml} / 10 \mathrm{~g})$, and a midline incision was made through the abdominal wall to expose the mesentery and mesenteric venules of 200- to 300- $\mu \mathrm{m}$ diameters. Exposed mesentery was kept moist by periodic superfusion using PBS (without $\mathrm{Ca}^{2+}$ or $\mathrm{Mg}^{2+}$ ) warmed to $37^{\circ} \mathrm{C}$. The mesentery was transluminated with a 12-V, 100-W, DC stabilized source. The shear rate was calculated using an optical Doppler velocity meter as described previously (61). Venules were visualized using a Zeiss Axiovert 135 inverted microscope (objective $\times 32$ ) connected to an SVHS video recorder (AG-6730; Panasonic) using a silicon-intensified tube camera (C2400; Hamamatsu). Leukocyte interaction with the endothelium vessel wall was recorded for 10 minutes each in 2-3 unbranched venules per mouse. Recorded images were analyzed as follows: the number of leukocytes passing a given plane perpendicular to the vessel axis during 1 minute was counted; leukocyte rolling/minute/venule for each mouse was determined by taking the average of four 1-minute counts during the entire 10-minute recording. The rolling velocity was determined as the number of leukocytes that traversed over a $250-\mu \mathrm{m}$-long and 200 - to $300-\mu \mathrm{m}$-wide segment. A leukocyte was considered to be adherent if it remained stationary for more than 20 seconds.

\section{Acknowledgments}

We thank Emily Perloff for assistance with VSMC preparation and slide processing, Colin Lamb for assistance with analysis of cell rolling videos, and Guohong Gao for assistance with BP measurements. We also acknowledge Robin MacDonald, Hou Xiang Xie, and Greg Martin at the Boston University School of Medicine transgenic/KO core for their superb expertise. This work was supported by National Heart, Lung, and Blood Institute grant HL13262 to K. Ravid and NIH Merit Award 41002 to D.D. Wagner. K. Ravid is an established investigator with the American Heart Association.

Received for publication January 17, 2006, and accepted in revised form April 25, 2006.

Address correspondence to: Katya Ravid, Department of Biochemistry, K225, Boston University School of Medicine, Boston, Massachusetts 02118, USA. Phone: (617) 638-5053; Fax: (617) 638-5054; E-mail: ravid@biochem.bumc.bu.edu. 
1. Londos, C., Cooper, D.M., and Wolff, J. 1980. Subclasses of external adenosine receptors. Proc. Natl. Acad. Sci. U. S. A. 77:2551-2554.

2. Van Calker, D., Muller, M., and Hamprecht, B. 1979. Adenosine regulates via two different types of receptors, the accumulation of cyclic AMP in cultured brain cells. J. Neurochem. 33:999-1005.

3. Brackett, L.E., and Daly, J.W. 1994. Functional characterization of the $\mathrm{A} 2 \mathrm{~b}$ adenosine receptor in $\mathrm{NIH}$ 3 T3 fibroblasts. Biochem. Pharmacol. 47:801-814.

4. Peakman, M.C., and Hill, S.J. 1994. Adenosine A2Breceptor-mediated cyclic AMP accumulation in primary rat astrocytes. Br. J. Pharmacol. 111:191-198.

5. Daly, J.W., Butts-Lamb, P., and Padgett, W. 1983. Subclasses of adenosine receptors in the central nervous system: interaction with caffeine and related methylxanthines. Cell. Mol. Neurobiol. 3:69-80.

6. Yaar, R., Jones, M.R., Chen, J.F., and Ravid, K. 2005. Animal models for the study of adenosine receptor function. J. Cell. Physiol. 202:9-20.

7. Fredholm, B.B., et al. 1994. Nomenclature and classification of purinoceptors. Pharmacol. Rev. 46:143-156.

8. Gao, Z.G., Kim, S.K., Ijzerman, A.P., and Jacobson, K.A. 2005. Allosteric modulation of the adenosine family of receptors. Mini Rev. Med. Chem. 5:545-553.

9. Brown, R., et al. 2001. Abolished tubuloglomerular feedback and increased plasma renin in adenosine A1 receptor-deficient mice. Am. J. Physiol. Regul. Integr. Comp. Physiol. 281:R1362-R1367.

10. Johansson, B., et al. 2001. Hyperalgesia, anxiety, and decreased hypoxic neuroprotection in mice lacking the adenosine A1 receptor. Proc. Natl. Acad. Sci. U. S. A. 98:9407-9412.

11. Salvatore, C.A., et al. 2000. Disruption of the A(3) adenosine receptor gene in mice and its effect on stimulated inflammatory cells. J. Biol. Chem. 275:4429-4434.

12. Tilley, S.L., Wagoner, V.A., Salvatore, C.A., Jacobson, M.A., and Koller, B.H. 2000. Adenosine and inosine increase cutaneous vasopermeability by activating $\mathrm{A}(3)$ receptors on mast cells. J. Clin. Invest. 105:361-367.

13. Zhao, Z., Makaritsis, K., Francis, C.E., Gavras, H., and Ravid, K. 2000. A role for the A3 adenosine receptor in determining tissue levels of cAMP and blood pressure: studies in knock-out mice. Biochim. Biophys. Acta. 1500:280-290.

14. Guo, Y., et al. 2001. Targeted deletion of the A3 adenosine receptor confers resistance to myocardial ischemic injury and does not prevent early preconditioning. J. Mol. Cell. Cardiol. 33:825-830.

15. Ledent, C., et al. 1997. Aggressiveness, hypoalgesia and high blood pressure in mice lacking the adenosine A2a receptor. Nature. 388:674-678.

16. Bailey, A., Ledent, C., Kelly, M., Hourani, S.M., and Kitchen, I. 2002. Changes in spinal delta and kappa opioid systems in mice deficient in the A2A receptor gene. J. Neurosci. 22:9210-9220.

17. Chen, J.F., et al. 2000. Selective attenuation of psychostimulant-induced behavioral responses in mice lacking $\mathrm{A}(2 \mathrm{~A})$ adenosine receptors. Neuroscience. 97:195-204.

18. Chen, J.-F., et al. 2003. Inactivation of adenosine A2A receptors selectively attenuates amphetamineinduced behavioral sensitization. Neuropsychopharmacology. 28:1086-1095.

19. Naassila, M., Ledent, C., and Daoust, M. 2002. Low ethanol sensitivity and increased ethanol consumption in mice lacking adenosine $\mathrm{A} 2 \mathrm{~A}$ receptors. J. Neurosci. 22:10487-10493.

20. El Yacoubi, M., et al. 2001. Absence of the adenosine $\mathrm{A}(2 \mathrm{~A})$ receptor or its chronic blockade decrease ethanol withdrawal-induced seizures in mice. Neuropharmacology. 40:424-432.
21. Svenningsson, P., et al. 2000. Regulation of the phosphorylation of the dopamine- and cAMP-regulated phosphoprotein of $32 \mathrm{kDa}$ in vivo by dopamine D1, dopamine D2, and adenosine A2A receptors. Proc. Natl. Acad. Sci. U. S. A. 97:1856-1860.

22. Dassesse, D., Ledent, C., Parmentier, M., and Schiffmann, S.N. 2001. Acute and chronic caffeine administration differentially alters striatal gene expression in wild-type and adenosine $\mathrm{A}(2 \mathrm{~A})$ receptor-deficient mice. Synapse. 42:63-76.

23. Armstrong, J.M., et al. 2001. Gene dose effect reveals no Gs-coupled A2A adenosine receptor reserve in murine T-lymphocytes: studies of cells from A2A-receptor-gene-deficient mice. Biochem. J. 354:123-130.

24. Ohta, A., and Sitkovsky, M. 2001. Role of G-protein-coupled adenosine receptors in downregulation of inflammation and protection from tissue damage. Nature. 414:916-920.

25. Martin, P.L. 1992. Relative agonist potencies of C2substituted analogues of adenosine: evidence for adenosine A2B receptors in the guinea pig aorta. Eur. J. Pharmacol. 216:235-242.

26. Balwierczak, J.L., et al. 1991. Comparative effects of a selective adenosine $\mathrm{A} 2$ receptor agonist, CGS 21680 , and nitroprusside in vascular smooth muscle. Eur. J. Pharmacol. 196:117-123.

27. Dubey, R.K., Gillespie, D.G., Osaka, K., Suzuki, F., and Jackson, E.K. 1996. Adenosine inhibits growth of rat aortic smooth muscle cells. Possible role of A2b receptor. Hypertension. 27:786-793.

28. Dubey, R.K., Gillespie, D.G., Shue, H., and Jackson, E.K. 2000. A(2B) receptors mediate antimitogenesis in vascular smooth muscle cells. Hypertension. 35:267-272.

29. Zhong, H., et al. 2004. A(2B) adenosine receptors increase cytokine release by bronchial smooth muscle cells. Am. J. Respir. Cell Mol. Biol. 30:118-125.

30. Feoktistov, I., et al. 2002. Differential expression of adenosine receptors in human endothelial cells: role of $\mathrm{A} 2 \mathrm{~B}$ receptors in angiogenic factor regulation. Circ. Res. 90:531-538.

31. Linden, J. 2005. Adenosine in tissue protection and tissue regeneration. Mol. Pharmacol. 67:1385-1387.

32. Hasko, G., Deitch, E.A., Szabo, C., Nemeth, Z.H., and Vizi, E.S. 2002. Adenosine: a potential mediator of immunosuppression in multiple organ failure. Curr. Opin. Pharmacol. 2:440-444.

33. Hasko, G., and Szabo, C. 1998. Regulation of cytokine and chemokine production by transmitters and co-transmitters of the autonomic nervous system. Biochem. Pharmacol. 56:1079-1087.

34. Yu, L., et al. 2004. Selective inactivation or reconstitution of adenosine A2A receptors in bone marrow cells reveals their significant contribution to the development of ischemic brain injury. Nat. Med. 10:1081-1087.

35. Ravid, K., Smith-Mungo, L.I., Zhao, Z., Thomas, K.M., and Kagan, H.M. 1999. Upregulation of lysyl oxidase in vascular smooth muscle cells by cAMP: role for adenosine receptor activation. J. Cell. Biochem. 75:177-185.

36. Yaar, R., Lamperti, E.D., Toselli, P.A., and Ravid, K. 2002. Activity of the A3 adenosine receptor gene promoter in transgenic mice: characterization of previously unidentified sites of expression. FEBS Lett. 532:267-272.

37. Kreckler, L.M., Wan, T.C., Ge, Z.D., and Auchampach, J.A. 2006. Adenosine inhibits tumor necrosis factor-alpha release from mouse peritoneal macrophages via $\mathrm{A} 2 \mathrm{~A}$ and $\mathrm{A} 2 \mathrm{~B}$ but not the $\mathrm{A} 3$ adenosine receptor. J. Pharmacol. Exp. Ther. 317:172-180.

38. Esmon, C.T. 2004. Crosstalk between inflammation and thrombosis. Maturitas. 47:305-314.

39. Frangogiannis, N.G., Smith, C.W., and Entman,
M.L. 2002. The inflammatory response in myocardial infarction. Cardiovasc. Res. 53:31-47.

40. Albelda, S.M., Smith, C.W., and Ward, P.A. 1994. Adhesion molecules and inflammatory injury. FASEB J. 8:504-512.

41. Collins, T., et al. 1995. Transcriptional regulation of endothelial cell adhesion molecules: NF-kappa B and cytokine-inducible enhancers. FASEB J. 9:899-909.

42. Hashimoto, M., et al. 1994. Production of soluble ICAM-1 from human endothelial cells induced by IL-1 beta and TNF-alpha. Inflammation. 18:163-173.

43. Dong, Z.M., and Wagner, D.D. 1998. Leukocyteendothelium adhesion molecules in atherosclerosis. J. Lab. Clin. Med. 132:369-375.

44. Hynes, R.O., and Wagner, D.D. 1997. Genetic manipulation of vascular adhesion molecules in mice. J. Clin. Invest. 100:S11-S13.

45. Bonder, C.S., et al. 2005. P-selectin can support both Th1 and Th2 lymphocyte rolling in the intestinal microvasculature. Am. J. Pathol. 167:1647-1660.

46. Cronstein, B.N. 1998. Adenosine and its receptors during inflammation. In Molecular and cellular basis of inflammation. C.N. Serhan and P.A. Ward, editors. Humana Press. Totowa, New Jersey, USA. 259-274.

47. Hasko, G., et al. 2000. Adenosine inhibits IL-12 and TNF-alpha production via adenosine A2a receptordependent and independent mechanisms. FASEB J. 14:2065-2074.

48. Lawrence, M.B., and Springer, T.A. 1993. Neutrophils roll on E-selectin. J. Immunol. 151:6338-6346.

49. Jones, D.A., Abbassi, O., McIntire, L.V., McEver, R.P., and Smith, C.W. 1993. P-selectin mediates neutrophil rolling on histamine-stimulated endothelial cells. Biophys. J. 65:1560-1569.

50. Chen, J.F., et al. 1999. A(2A) adenosine receptor deficiency attenuates brain injury induced by transient focal ischemia in mice. J. Neurosci. 19:9192-9200.

51. Day, Y.J., et al. 2003. Renal protection from ischemia mediated by A2A adenosine receptors on bone marrow-derived cells. J. Clin. Invest. 112:883-891. doi:10.1172/JCI200315483.

52. Linden, J., Auchampach, J.A., Jin, X., and Figler, R.A. 1998. The structure and function of A1 and A2B adenosine receptors. Life Sci. 62:1519-1524.

53. Feoktistov, I., and Biaggioni, I. 1997. Adenosine A2B receptors. Pharmacol. Rev. 49:381-402.

54. Jones, M.R., et al. 2004. A(3) adenosine receptor deficiency does not influence atherogenesis. J. Cell. Biochem. 92:1034-1043.

55. Ravid, K., Doi, T., Beeler, D.L., Kuter, D.J., and Rosenberg, R.D. 1991. Transcriptional regulation of the rat platelet factor 4 gene: interaction between an enhancer/silencer domain and the GATA site. Mol. Cell. Biol. 11:6116-6127.

56. Zimmet, J.M., Ladd, D., Jackson, C.W., Stenberg, P.E., and Ravid, K. 1997. A role for cyclin D3 in the endomitotic cell cycle. Mol. Cell. Biol. 17:7248-7259.

57. Thompson, A., et al. 1996. Deregulated expression of c-myc in megakaryocytes of transgenic mice increases megakaryopoiesis and decreases polyploidization. J. Biol. Chem. 271:22976-22982.

58. Zhang, Y., et al. 2002. Signaling by the Mpl receptor involves IKK and NF-kappaB. J. Cell. Biochem. 85:523-535.

59. Makaritsis, K.P., et al. 1999. Role of the alpha2Badrenergic receptor in the development of saltinduced hypertension. Hypertension. 33:14-17.

60. Johns, C., Gavras, I., Handy, D.E., Salomao, A., and Gavras, H. 1996. Models of experimental hypertension in mice. Hypertension. 28:1064-1069.

61. Frenette, P.S., et al. 1998. Platelet-endothelial interactions in inflamed mesenteric venules. Blood. 91:1318-1324. 